\begin{tabular}{|c|c|c|}
\hline Beitr. Ent. & Keltern & ISSN 0005-805X \\
\hline $\mathbf{5 9}(2009) 2$ & S. $319-323$ & 15.12 .2009 \\
\hline
\end{tabular}

\title{
Nesting behaviour, male territoriality and larval development of Eremnophila binodis (FABRICIUS) from Brazil
}

\section{(Hymenoptera: Sphecidae)}

With 4 figures

Sandor Christiano Buys

Summary

Aspects of the nesting behaviour, male territoriality and larval development of the solitary caterpillar-hunting wasp Eremnophila binodis (FABRICIUS) are described, based on observations carried out in the Biological Reserve of Poço das Antas, an area covered by Atlantic Tropical rain forest in southeastern Brazil.

Key words

Biology, territorial behaviour, immature, solitary wasp, Ammophilini

\section{Zusammenfassung}

Aspekte des Nestbaus, des Territorialverhaltens der Männchen und der Larvalentwicklung der solitären Grabwespe Eremnophila binodis (Fabricius) werden behandelt. Die Studie beruht auf Beobachtungen, die im Reservat Poço das Antas im südöstlichen Brasilien, einem von tropischen Regenwald bedeckten Gebiet, durchgeführt wurden.

\section{Introduction}

The tribe Ammophilini is a widely distributed group of six genera of solitary wasps that usually hunt on caterpillars to provision their nests (BOHART \& Menke 1976). Although some species of Ammophila Kirby and Podalonia Fernald have been extensively biologically studied (see BoHART \& Menke 1976, Pulawski 2009), the biology of the other four genera of Ammophilini is very poorly known. Among these is the genus Eremnophila Menke, which contains nine species distributed in the Neotropical region (Menke 1964, 1966). The knowledge on the biology of Eremnophila is restricted to short fragmentary observations on E. aureonotata (CAmeron) [Рескham \& Peckham 1898 as Ammophila gracilis Lepeletier de SAINT FARgeau, Rau 1922 as Ammophila abbreviata (Fabricius), Krombein 1958, Evans 1959, Lechner 2006], E. binodis (Fabricius) (Buys 1999), E. eximia (Lepeletier de Saint Fargeau) (Genise 1981) and E. opulenta (Guérin-Méneville) (Richards 1937). In the present paper aspects of the reproductive biology and larval development of $E$. binodis are described. Notes on the male behaviour are also provided. The study was carried out in the Biological Reserve of Poço das Antas, an area of Tropical Atlantic rain forest in the southeastern Brazil (Rio de Janeiro State, cities of Silva Jardim and Casimiro de Abreu). The area was visited always every month from May 2000 to April 2001. Voucher specimens were deposited in the Museu Nacional - Universidade Federal do Rio de Janeiro (Rio de Janeiro, Brazil). 


\section{Results}

\section{Habitat and annual occurrence:}

Females of E. binodis were observed throughout the year, commonly resting on plants or hovering over the low vegetation of marginal portions of unpaved roads crossing forested areas. However, the nests were not easily found; perhaps because the females use to dig their nests beneath the low vegetation, as occurred in one case observed by BuYs (1999), in which the nest was beneath tufts of grass. Anyway, the three nest examined were found in compacted earth in the marginal portion of roads, in sites without vegetation or litter.

\section{Digging behaviour, nest structure and provision:}

In order to search the nesting site the females walked on the ground antennating the soil and dug a number of short tentative burrows that they closed with stones and earth. Complete excavation of two nests was observed. Firstly, the females cut the soil with the mandibles and threw the earth backward beneath the body in several directions with the forelegs. After about 1 minute the females started to hold the earth between the mandibles and the forelegs and discarded it during short quickly flights. One female repeatedly flied about $5 \mathrm{~cm}$ from the nest and not more than $10 \mathrm{~cm}$ from the ground to discard the earth; the other female behave similarly, but she flied up to $20-25 \mathrm{~cm}$ from the nest. The females sometimes found stones during the excavation, which they transported walking on the ground and dropped in a similar distances to those that they discarded the earth in flight. Apparently the females were not able to fly carrying the stones because they are too heavy. One female spent 35 minutes to complete the excavation of the nest. The females drove away ants from the nest surroundings during the nest excavation. The nests were L-shaped burrows; the principal canals were perpendicular to the ground and the cells were parallel to the ground. One nest was $4.8 \mathrm{~cm}$ deep and contained only one large not identified lepidopterous larva.

\section{Temporary closure of the nest:}

Soon after the nests were ready, the females temporarily closed their entrances. Firstly she put a larger object, which fitted to the nest entrance and bore the weight of debris and sand that she put over the entrance. They carefully selected these objects near to the nests; one female took a piece of dried mud that was $50 \mathrm{~cm}$ from the nest, another female did not distance more than $10 \mathrm{~cm}$ and finally selected a stone to close the nest. Subsequently, the females put sand over the entrance that they threw backward beneath the body with the forelegs. One female compacted with the mandible the earth over the nest; in this moment she emitted an easily audible buzzing sound. In two occasions the temporary closing of the nest spent respectively about 5 minutes and 10 minutes. Soon after closing the nest, the females started to walk on ground, touching the soil with the antennae, similarly they did when are searching for a nesting site.

\section{Male territorial behaviour:}

Males were observed a number of times flying over herbaceous plants within fixed areas in sunny open places in the marginal portions of an unpaved road, but the behaviour of one male was studied in detail and described as follows. The male repetitively flied in a trajectory within about $30 \mathrm{~m}$ and usually about $30-50 \mathrm{~cm}$ from the ground. The trajectory was coarsely approximating in a straight line and he did not change the flying direction before completing the entire trajectory. Sometimes he rested on leaves for some minutes, but after that he continued flying in the same direction. He spent 7-10 minutes to complete the trajectory. Sometimes the resident male found a co-specific male flying in the area, then they behave stereotypically flying face to face in a spiral course upward. Two times the intruder male approximated and hovered over the resident male when he was landed on the vegetation, this behaviour also stimulated the stereotypical be- 
haviour above described. When the resident male found a male of Prionyx thomae (Fabricius) (Hymenoptera: Sphecidae) feeding in flowers of Boreria, he charged aggressively against him apparently with physical contact and the male of $P$. thomae departed from the area

\section{Precopulatory behaviour:}

Wasps in copulation were commonly observed on the ground or on the vegetation. In one occasion the precopulatory behaviour was studied in detail. One female and two males walked on the ground antennating the soil apparently in random trajectories within an area of about $1 \mathrm{~m}^{2}$. They behave similarly to females in searching for a nesting site or when the females complete the nest closure and depart from the nesting site walking. The two males remained distant at least $50 \mathrm{~cm}$ from the female. Sometimes a male charged against the other, apparently aggressively and with physical contact. The three specimens remained about one hour behaving in that way. Suddenly one male quickly flied and grasped the female neck with the mandibles and remained attached in a constant position. He moved his gaster circularly, exposing his genitalia and trying the copulation, whereas the female circularly moved her gaster apparently to escape of the male. They flied together and landed on a leaf of a tree about $2 \mathrm{~m}$ from the ground. In this moment they were collected using a plastic jar, but they remained attached in the precopulatory position during about three hours inside the collecting jar, both of them remained for a long time moving circularly the gaster as above described.

Development and larval behaviour in laboratory conditions. One prey bearing the wasp's egg was created in laboratory (Figs 1-4). The egg was yellow, cylindrical with the extremities rounded; it was laid on the side of the fifth abdominal segment of the prey. The egg hatched in the day after the oviposition and the newly emerged larva penetrated the head and part of anterior portion its body into the prey body in the same place where the egg was laid. During the three first days of development, the larva remained immobile probably feeding by sucking (Figs 1-2). In the fourth day after the egg hatching, the larva gained movement and started to externally consume the prey (Fig. 3) and completely feed the prey body, except the head capsule (Fig. 4). The larva was initially intense green, but the colour became less intense as the larva grew. Forty two days after the egg hatching an adult female emerged from the cocoon.

\section{Discussion}

The digging behaviour, nest structure and prey manipulation of E. binodis are in general similar to the observed in species of Ammophila (e.g. Evans 1959, Powell 1964). The behaviour of closing tentative burrows during the searching for nesting sites is uncommon in sphecid, but was observed for example in species of Prionyx (Buys 2006). The few provisioned nests of different species of Eremnophila analysed until now bore only one prey item per offspring (RICHARDS 1937, Krombein 1958, Evans 1959, Genise 1981), suggesting that this genus in general rule use one prey per cell. The present observation on E. binodis corroborates this hypothesis. Females of Podalonia also provide one caterpillar per cell (e. g. Bohart \& Menke 1976); in the same way as that Hoplammophila aemulans (KoHL) (Tsuneki 1968). On the other hand, species of Ammophila can use one to several caterpillars per cell (e.g. Evans 1959, Powell, 1964, Field 1992).

The male behaviour of $E$. binodis was interpreted as territorial because the male has a fixed area and drive away other co-specific males and even males of other species. An identical territorial behaviour was described in the acridid-hunting Sphecini Prionyx thomae (Buys in press), but apparently was not observed in other sphecid species; even the stereotypical motor pattern caused 

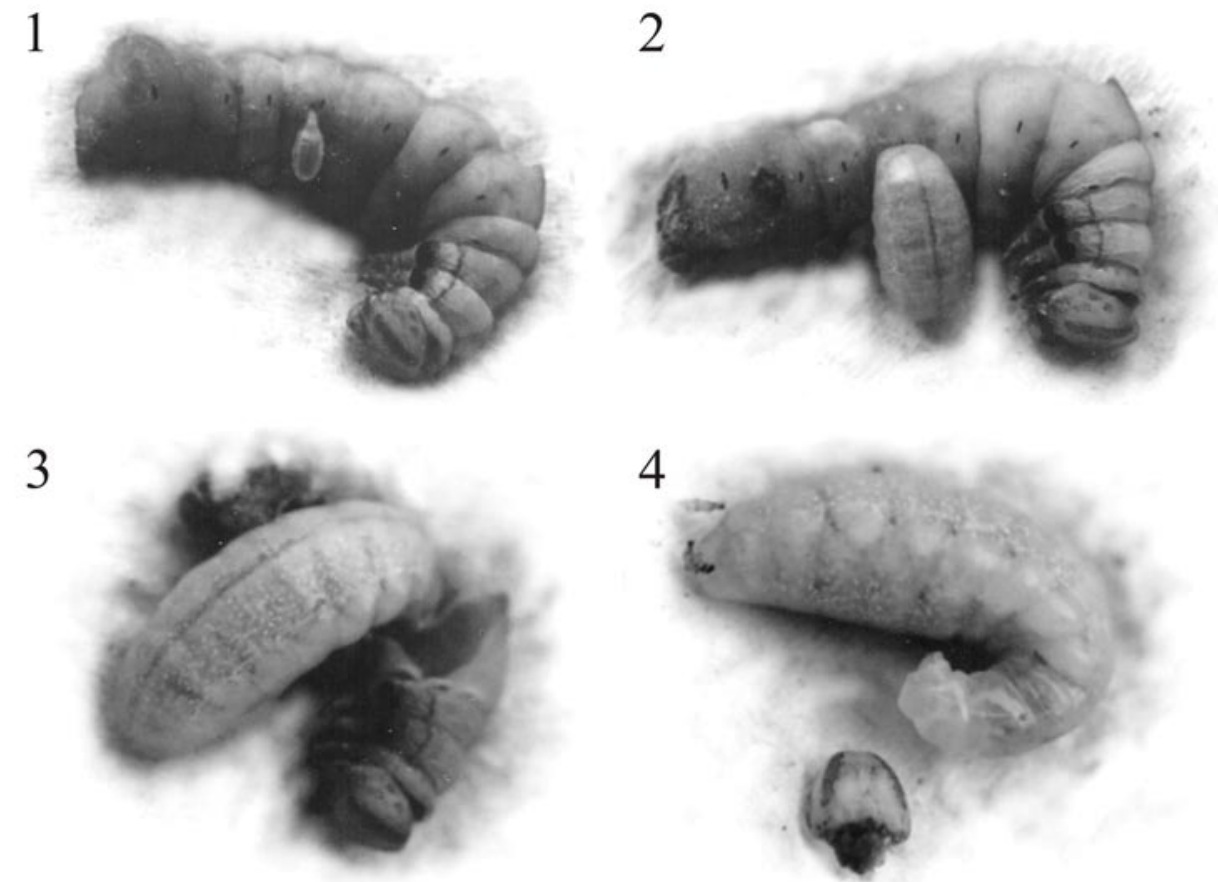

Figs 1-4: Laval development of a female Eremnophila binodis consuming a caterpillar. 1 Newly emerged larva; 2 larva immobile feeding the prey probably by sucking; 3 larva in the fourth day of development consuming externally the prey; 4 full-grown larva, the head capsule was the only portion of the prey that was not consumed.

by the encounter of two co-specific males of $E$. binodis is identical to those of $P$. thomae. Hager $\&$ KurCzewski (1985) described that males of Ammophila harti (Fernald) also flied over fixed areas, but they did not defend it, thus this behaviour could not be interpreted as territorial. Besides the hypothesis of the male behaviour in Ammophila, Eremnophila and Prionyx having evolved independently, the hypothesis of males maintaining fixed areas being basal in the lineage of the Ammophilini + Sphecini must be considered.

Menke (1964) depicted a photograph by E. S. Ross of a couple of E. melanaria (Dahlbom) in precopulatory position and LECHNER (2006) depicted a photograph of E. aureonotata in copulation. The positions of both of these species are similar to the observed in E. binodis. Males of Eremnophila have an acute projection in the labrum (illustrations in Menke 1964) that apparently is used to fit behind the head of the female during the precopulation and copulation. The particularly complex and well developed male genitalia of Eremnophila (illustrations in Menke 1964) possibly also have some function in maintaining the female attached during the copulation.

The larval development of E. binodis is general lines similar to that observed in species of Ammophila (e.g. Evans 1959, Grandi 1961).

\section{Acknowledgements}

I am grateful to Conselho Nacional de Desenvolvimento Científico e Tecnológico (CNPq) and Fundação Carlos Chagas de Amparo à pesquisa do Estado do Rio de Janeiro (FAPERJ) for the financial support. I also thank Gary Lechner for sending a reprint of his paper on Eremnophila aureonotata. 


\section{References}

Bohart, R. M. \& Menke, A. S. 1976: Sphecidae wasps of the world - a generic revision. - Pp. ix + 695 . - Berkeley: University of California Press.

BuYs, S. C. 1999: Notes on the nesting behavior of Eremnophila binodis (GuÉrIN) (Hymenoptera, Sphecidae). - Entomological News 110: 184-186.

Buys, S. C. 2006: Nesting behaviour and larval biology of Prionyx fervens (Linnaeus) (Hymenoptera: Sphecidae) from Brazil. - Revista Brasileira de Zoologia 23: 1277-1279.

Buys, S. C. In press: Reproductive behaviour and larval development of Prionyx thomae (Fabricius) from Brazil (Hymenoptera: Sphecidae). - Beiträge zur Entomologie, Keltern 59 (2009) 2

Evans, H. E. 1959: Observations on the nesting behavior of digger wasps of the genus Ammophila. American Midland Naturalist 62: 449-473.

FIELD, J. 1992: Patterns of nesting provisioning and parental investment in the solitary digger wasp Ammophila sabulosa. - Ecological Entomology 17: 43-51.

Genise, J. F. 1981: Observaciones sobre el comportamiento de nidificación Eremnophila eximia (Lep.) (Hymenoptera, Sphecidae). - Ecosur 8: 47-49.

Hager, B. J. \& Kurczewski, F. E. 1985: Reproductive behaviour of male Ammophila harti (Fernald) (Hymenoptera: Sphecidae). - Proceedings of the Entomological Society of Washington 87: 597-605.

Grand, G. 1961: Studi di un Entomologo sugli Imenotteri superiori. - Bollettino dell'Istituto di Entomologia della Università di Bologna 25: i-xv, 1-659.

Krombein, K. V. 1958: Biological notes on some wasps from Kill Devil Hills, North Carolina, and additions to the faunal list (Hymenoptera, Aculeata). - Proceedings of the Entomological Society of Washington 60: $97-110$.

LeChner, G. K. 2006: Copulation in Eremnophila aureonotata (Hymenoptera: Sphecidae) in Iowa, U.S.A. - Entomological News 117 (3): 353-354.

Menke, A. S. 1964: A new subgenus of Ammophila from Neotropical region (Hymenoptera: Sphecidae). - The Canadian Entomologist 96: 874-883.

Menke, A. S. 1966: The genera of the Ammophilini (Hymenoptera: Sphecidae). - The Canadian Entomologist 98: 147-152.

Pескнам, G. W. \& Рескнам, E. G. 1898: On the instincts and habits of solitary wasps. - Wisconsin Geological and Natural History Survey, Bulletin No 2, Scientific Series 1: I-IV, 1-245.

Powell, J. A. 1964: Additions to the knowledge of the nesting behavior of North American. Ammophila (Hymenoptera: Sphecidae). - Journal of the Kansas Entomological Society 37: 240-258.

Pulawski, W. J. 2009: Catalog of Sphecidae sensu lato. Available from: <http: // www. calacademy. org /research / entomology / Entomology _ Resources / Hymenoptera / sphecidae/ Genera _ and _ species _ PDF / introduction. htm.>. Accessed on 09.06.2009.

RAU, P. 1922: Ecological and behavior notes on Missouri insects. - Transactions of the Academy of Science of St. Louis 24: 1-71, pls I-VIII.

Richards, O. W. 1937: Results of the Oxford University expedition to British Guiana, 1929. Hymenoptera, Sphecidae and Bembicidae. - Transactions of the Royal Entomological Society of London 86: 101-118.

Tsuneki, K. 1968: The biology of Ammophila in East Asia (Hymenoptera, Sphecidae). - Etizenia 33: $1-64$.

\section{Author's adress:}

Sandor Christiano Buys

Departamento de Entomologia,

Museu Nacional, Universidade Federal do Rio de Janeiro

Quinta da Boa Vista, São Cristóvão, 20.940-040, Rio de Janeiro, RJ, Brazil

E-mail: sbuys@biologia.ufrj.br

\section{Subject editor:}

Prof. Dr. J. OehlKe 